\title{
Emotional Repercussions in Fathers Triggered by Paternity Testing
}

\author{
Fabíola de Freitas Schäfer ${ }^{1 *}$, Edson Júnior Silva da Cruz ${ }^{2}$, \\ Júlia Sursis Nobre Ferro Bucher-Maluschke"1, Janari da Silva Pedroso ${ }^{2}$ \\ ${ }^{1}$ Catholic University of Brasília, Brasília, Brazil \\ ${ }^{2}$ Federal University of Pará, Belém, Brazil \\ Email: ^fabiolaschafer@gmail.com
}

How to cite this paper: Schäfer, F. F., da Cruz, E. J. S., Bucher-Maluschke, J. S. N. F., \& Pedroso, J. S. (2017). Emotional Repercussions in Fathers Triggered by Paternity Testing. Psychology, 8, 815-827. https://doi.org/10.4236/psych.2017.86052

Received: February 11, 2017

Accepted: April 25, 2017

Published: April 30, 2017

Copyright $\odot 2017$ by authors and Scientific Research Publishing Inc. This work is licensed under the Creative Commons Attribution International License (CC BY 4.0).

http://creativecommons.org/licenses/by/4.0/

\section{c) (i) Open Access}

\begin{abstract}
The present study discusses the emotional repercussions in parents triggered by the process of Deoxyribonucleic Acid (ADN) testing for paternity acknowledgment. The research adopts a qualitative focus for data analyses and uses as tools: interviews with open and closed questions to deal with sociodemographic data for profiling the participants, history of paternity and identification of the father, and family experience of parents and their children. Four men took part in the study, all of them coming from South and Midwest regions of Brazil. Data were categorized according to content analysis. The results evidenced various forms of reactions in fathers triggered by the ADN testing, such as feelings of insecurity, surprise, affection and endearment. The study allowed contributions to analyze paternal psychology concerning feelings of fathers and their care about their children.
\end{abstract}

\section{Keywords}

Paternity, Children, ADN Testing, Feelings, Emotional Repercussions

\section{Introduction}

Researches in the field of developmental and family psychology have focused as an objective of investigation and analysis in the maternal relationship with babies and children. This way, as paternity in Brazil is still insufficiently investigated by researchers, we realized the need for more studies in this area, since presence and performance of the father in the family environment is important for both the relationship with his children and the family dynamics as a whole (Brasileiro, 2002).

Once historical aspects of making the paternal role are retrieved, it is possible to realize how traditional paternity was organized and gradually deconstructed, 
in a movement that influenced very intensely the way this phenomenon is experienced by modern men (Staudt \& Wagner, 2008). In the classical patriarchal society, matters of affection and care were depreciated in the sake of social power. The male supremacy was associated with ideas of primacy, strength, power, domination, aggressiveness, authority and submission of others, who were usually wives and children (Muraro, 1992; Silva, 2005).

Modernity, in its turn, brought along human autonomy, search for liberty and, at the same time, querys and doubts about the traditional model of being a father. Honor and physical strength, so much valued in patriarchy, lost ground to money and success, what imposed the role of family provider on the working man of capital industrial order, forcing him to move away from his own family in order to be able to support it (Silva, 2005). Simultaneously, searching for production and profit attracted the woman to the labor market. With her entry in the capitalist world in the 20th century, the family model needed to be restructured, as homes no longer had the exclusive dedication of the woman and mother.

As women entered the labor market, men started to share housework and care of children with their wives, that is, at the same time women entered public space, once exclusive to men, men in turn went back to the family environment with tasks once exclusive to women (Muraro, 1992; Satudt \& Wagner, 2008; Lima, Pedroso, Cruz, \& Aguiar, 2016). In order to perform these tasks adequately, men have remade their paternal role and posture. Men no longer had their social role tied only to economic power, given that feelings and affection became the anchor of the relationship between fathers and children (Sutter \& Bucher-Maluschke, 2008).

In the 1960s, emergence of new ways of family life advanced with the biomedical researches influenced by different forms of procreation and demands for the prenatal testing (Brito, 2008). From 1980s on, there was a slight increase in number of studies about fathers due to the increasing number of divorces and remarriages. Therefore, such debate reinforced the guidelines of the International Convention on the Rights of the Child in 1989, which put as a right of the child to be raised by both their mother and father, regardless of the emotional situation of the couple.

Recently, studies about paternity had a significant increase in the field of human and legal sciences (especiality in Law and Psychology) due to modifications in multiple family arrangements. It is recognized that family has been modified due to demands of the modern society, what impacts directly the current family dynamics (Balancho, 2004; Antunes et al., 2010).

A research was carried out based on these new changes, in order to investigate experiences and feelings of fathers concerning their own paternity and their own fathers. Participants were eight men, fathers for the first time, with ages between 28 and 41, who answered to a semi-structured interview. Content analysis of the reports revealed that fathers described themselves as participants in care tasks as well as helpful and concerned individuals about their child's education and 
health. Differences and similarities concerning their own father in the way of exercising paternity showed that while they wanted to replicate the right things about their fathers, they also tried not to repeat mistakes from the past (Gabriel, \& Dias, 2011).

It is understood that father's participation in education and care of their children is important, since it exerts positive influences over the affective relationship of the family, demystifies the social image of the traditional father, the only one who contributed to the subsistence of the home and performed small tasks in basic care. It also helps to make the paternal role more visible to society, thus promoting and fomenting such practice.

The male presence in child care and its importance were the subject of a study carried out by Crepaldi et al. (2006). Through a semi-structured interview, they investigated how mothers perceived this relationship, comparing mothers who had children enrolled in a public day care center to mothers who were waiting for a place in those institutions. Results showed that according to the perception of mothers, fathers were more present in leisure activities, such as taking children for walks, playing or watching movies, however, the same fathers were seen as absent in other activities of care, such as, helping with homework from school.

Literature also shows that child care becomes a task of the mother when separation of the parents occurs, since it is the maternal care model that sounds more stable, while questions about who the father is and what his tasks are emerge more often (Hurstel, 1999; Gabriel \& Dias, 2011; Carvalho et al., 2012). Such questions about who should be responsible for child care, frequently arrive at the Judiciary as a discussion for dispute settlement (Brito, 2008). However, according to data from the Brazilian Institute of Geography and Statistics (IBGE) (2010), percentage of parents who opted for joint custody almost doubled in the last ten years. The highest proportion is found in the city of Salvador (BA), where $46.5 \%$ of children from separated couples are "under both father and mother custody". It is estimated that the situation of separated parents affects 20 million children and, according to IBGE, only $6.8 \%$ of these children are appropriately attended.

According to Sousa and Samis (2008), during assistance provided by the Psychology service in a law office in Brazil, it was possible to observe litigant behavior in many mothers about their children and ex-spouses. Frequently, these mothers put themselves as the ones who could do anything when it came to their child, who became their object. Mothers imposed their rules and disposed, in due time, of that one who they saw unfit to be the best or ideal father of their child. In that scenario, children were used as objects of dispute, what ended up being a way of maintaining marital litigation.

A study was carried out based on this litigation discussion, in order to investigate the opinion of young adult children from separated parents with post-divorce families on how they perceived life changes occurring due to marital breaking up of their parents, specially concerning intra-family living. In this 
research thirty individual interviews were conducted with people from middle classes of the population, residents in Rio de Janeiro, aged between 21 and 29 years old, children from separated parents. The results showed that separation of parents was expected by some of the interviewees and a surprise to others. Such process caused situations perceived as unpleasant by some children, among which we highlight the fact of being placed at the center of the quarrels, estrangement of the father who left home and difficulty of accepting new relationships of their parents (Brito, 2007).

After the discussions above, we realize that paternity is still a subject that demands further discussion and clarification about its importance in life of children. The present study discusses the topic of paternity based on the ADN testing, and on the repercussions in fathers triggered by requirement of genetic testing for paternity acknowledgement. Objectives were to characterize the social profile of participants; identify feelings of fathers concerning the test; and analyze forms of relationship described between fathers and children.

\section{Material and Methods}

The approach used was qualitative research. Since we understand it is capable of a greater understanding and analysis of collected data, focus on the researched data showed the perspective of content given by participants. The way each father experienced and informed his parental relationship was important and singular, since the meaning or the intent they transmitted to experiences they had were the central point of analysis.

\subsection{Participants}

Four men who were involved in the process of ADN testing for acknowledgment of paternity took part in this research. All names were changed to aliases in order to assure secrecy. The first participant was Sávio, who was 27 years old, had not finished elementary school, was an electrician, was separated and had a monthly income of $\mathrm{R} \$ 1200$ - 1400; the second participant was Marcelo, who was 18 years old, had finished high school, was self-employed, was single and had a monthly income of $\mathrm{R} \$ 800$ - 1000; the third participant was Wilson, who was 45 years old, had not finished elementary school, worked for a business company, was in a common-law marriage and had had a monthly income of $\mathrm{R} \$ 800-1000$; and the fourth participant was Antonio, who was 31 years old, had not finished college degree, was unemployed and therefore had no income.

We chose intentional convenience sampling for selection criteria. The intentional sampling allows researchers free selection of individuals according to the research objectives and makes possible a further refinement of the selection process, producing important information and enriching the topic to be investigated (Turato, 2003). Criteria used for inclusion of participants was their acceptance in participating as volunteers in the research after invitation and their condition of being in the process of ADN testing. 


\subsection{Location of the Research}

The research was carried out in two Brazilian capital cities: Porto Alegre/RS and Brasília/DF. Data were collected at the Office of Public Defense of Rio Grande do Sul and at the Office of Public Defense of Distrito Federal, at the Psychosocial Nucleus of this institution. As the research involved communication of ADN test results, the cognizance of the result was taken at the District Forum, in a room of the Judiciary Power of Rio Grande do Sul and at the Psychosocial Nucleus in Brasília. We highlight that those institutions are also involved in the state projects: Paternidade Responsável (Responsible Paternity), Paternidade Consciente (Informed Paternity), Pai Presente (Present Father), Paternidade Legal (Legal Paternity); which had incentive from the Magistrate National Justice in order to increase the acknowledgment of paternity in Brazil.

\subsection{Tools and Material}

An interview was conducted with open and closed questions, which collected personal data of participants and topics mentioned in the objectives. That way, interview was organized in three parts: bio-demographic data (age, place of birth, home town, education, religion, profession, income and marital status); revelation of paternity (reaction when they learned about the possibility of having a child, feelings when they learned about the request for paternity investigation); the family living and the paternity practiced (relationship with other children, evaluation of paternal participation in the upbringing of children).

The interviews were recorded and transcribed in order to preserve accuracy of collected data. Non-verbal manifestations considered relevant were manually registered, such as meaningful gestures which denoted anxiety, certain emotional restraints in answers or prolixity, laughter, crying and facial expressions of joy and anger. Usage of colloquial expressions, slangs, pauses, hesitations, emphasis and others was preserved.

\subsection{Ethical Considerations of the Research}

The research was authorized by the Ethics Committee in Research of the Catholic University of Brasilia, in accordance with n. 157.196 and the participants signed the Free and Informed Consent Form.

\subsection{Procedures}

For carrying out the research, the first phase was to obtain the authorization from the defender's office in Brasília (DF) and Porto Alegre (RS). After the defender's office permission, we got in contact with fathers in the physical environment of the institutions, by personal invitation, then the Free and Informed Consent Form was presented to participants, which explained the purpose of the research, its contributions and benefits, and brought researchers' data (phone number, email and physical address), in case fathers wanted to ask any questions about the study. After acceptance of contributing to the research, data collection was carried out with fathers. Thereafter, we thanked them for their participation 
and subsequently started data analysis.

\subsection{Data Analysis}

Data treatment was made according to the method of content analysis proposed by Bardin (2004), which consists in an analysis of communication that allows interpretative inference of the messages. The content analysis was carried out in three phases: pre-analysis; exploration of the material; and treatment of results, inference and interpretation. In pre-analysis, we organized the material collected during the interviews and its transcriptions by usage of floating reading. Thereafter, we started content selection, which was analyzed according to the guiding questions and purposes of the research.

Subsequently, indicators were developed to substantiate the final interpretation. The coding of data in grids was made by transforming the primary information into units or descriptors, and became a description of the content's main characteristics. Therefore, categorization of data used thematic categories as semantic criteria, aiming to include meanings showed by presence or frequency of appearance to the selected analytic objective, supported by theoretical reviews used in the process. Moreover, this categorization passed by the analysis of independent judges, who are researchers in the field and had an assent (Bardin, 2004).

\section{Results and Discussion}

This research analyzed paternal emotional repercussions triggered by ADN testing process, which involve legal matters. In most cases, children stay with their mothers, it is acknowledged that men face a lot of difficulties in performing tasks related to paternity, such as supporting and monitoring their children's development.

\subsection{Fathers and Expectations before Paternity}

The requests for ADN tests were made through the judiciary system in all cases. The expectations about paternity and what kind of father they intended to be were observed in reports from two interviewees, according to the lines below:

[Kind of father intended to be] “... a father really present... right. And even raise the best way I can, right. Provide some quality education to him. And try to enjoy the most I can the moment with him, I mean" (Interview, Antonio).

"I believe I am going to be a very friendly father, I mean. The best way possible". (Interview, Antonio).

It is understood as from the statements above that fathers have good expectations concerning their presumed children and that they, in addition to showing willingness to take part in basic care, such as providing good education, also showed interest on being present in the affective life of their children. Such conceptions might have had some influence on new family configurations, where 
fathers have a more active role, not only by providing material/financial support, but also emotional support. Such lines show a rupture from the traditional model of what it means to be a father in the intra-family dynamics, and what are his roles and tasks.

Nowadays father comprises ruptures and continuities, and according to literature, many men are not yet comfortable with the new paternal role, often because they did not experience that at their own homes (Dantas et al., 2004; Gomes \& Resende, 2004; Polity et al., 2004; Silva, 2005; Brito, 2008; Sousa, 2008; Sutter \& Bucher-Maluschke, 2008; Brito et al., 2010; Goetz \& Vieira, 2010). Studies show that many men feel the need for participating actively in the life of their children, and that they are interested on having an increasingly more important role in upbringing their offspring, as it can be seen in the lines below:

[Marcelo-about the future as a father] "A present father, right... Be visiting, right. Be knowing about the school, right, getting informed about the studying. This kind of thing" (Interview, Marcelo).

[His relationship with the children from the marriage] "I demand. I am strict. I am. I am executioner. (laughter) And I do not accept they flunk. Because everything they ask me I give, got it? So, I give to receive. What do I want to receive? The study. So tomorrow, later, they can be someone in life, right". (Interview, Wilson).

[Concerning this new paternity] “... something I did not do then with them, right, I do with him, got it? Then I did not give too much attention, kinda, right, I was a little bit distant, I worked a lot..." "I am going to be a more present father" (Interview, Wilson)

Moreover, it is also possible to notice a good expectation of a presumed paternity of these men, who end up idealizing in a positive way how they could play this role and task. According to the understanding of Andrade, Costa and Rossetti-Ferreira (2006), contemporary father is that one who wants to break the explanatory model of traditional family, in which he had only a provider role. And he does so by showing his emotions and by taking part in the everyday activities of his child, feeling, most of the times, pleased by that. Paternity can be seen as part of making the identity of the individual, since it promotes transformation in couple's life and in the way of connecting to the world. Furthermore, it is important for making the identity of the child, since it serves as a reference model. It is worth adding that the exercise of paternity very often depends on the way fathers relate affectively with the mother of their children. Generally, when parents have a relationship of conflict, filial interaction suffers negative consequences.

Burdon (1998) identifies that there is one significant barrier to paternal participation and that men are, very often, excluded from a deeper involvement with their children by their own partners. For this author, a "realignment of the structures of maternal power" is necessary inside the family. This way, sexist attributions of maternal and paternal roles are ingrained and show that some paradigms are hard to break. 
The way man relates to the mother of his child and the way his relationship developed with his own father will influence the making of paternity. In that sense, Benczik (2011); Oliveira and Silva (2011) state that there is an adjustment of men concerning conflicts of their fathers, so that when they feel their fathers distant, their intent is to become different fathers from the ones they had. These same researchers state that paternity requires time for the acceptance of changes, since it might produce fantasy and feelings related to his own childhood. For Silva and Piccinini (2007), beliefs and expectations concerning the paternal role in upbringing the children underwent a great transformation during last decades. Little is known, however, about the way those changes influence the routine of fathers and children, and how fathers have assessed themselves in that role.

Sutter and Bucher-Maluschke (2008) indicate the idea of the "new father" as opposed to the image of the "meal ticket" father. In that sense, he would be present since birth, offering time and dedication, not only working. The understanding of Ramires (1997), according to the results of his research about the exercise of paternity in current days, adds to that conception the assertion that the new father is the one who, in addition to expressing the need and desire for taking part in upbringing his children, also prioritizes paternity over other fields of life. In the lines below, it becomes clear how expectation of paternity appears.

[About the expectation of paternity] "Look, I want to try to be the best, I mean. I am very playful... I am very thoughtful in situations... I am a person who likes to talk, I am not very, my reprimand is a moment of conversation, things like that... Being a present father and trying to raise the best way possible so that in the future he has..." (Interview, Antonio).

Expectation of paternity reveals an idealization of how this role should be developed. Man makes himself as a father in his relationship with the child, that is, man undergoes a transformation as he lives the paternity. Manfroi et al. (2011) state that the father as well, not only the mother, would be able to develop bonds of attachment to his children, albeit with distinguished skills of responsibility and sensitivity, and that his role would be relevant to the child during both their normal and pathological development.

Paternity is an experience built on many sociocultural or relational levels - the way others see it, beyond the relationship with the mother of his child, has great influence on the way it will be lived. On the other hand, previous experiences are also at stake in making the paternity, and the way they will be used in the present depends on singularities of each man. In the same direction, Gomes and Resend (2004) believe that emotional involvement is the differential of contemporary father. It is not only about adopting different attitudes from those expressed by traditional father, but also accepting feelings and ambivalences raised by that relationship.

\subsection{Feelings Triggered by ADN Testing}

Due to the high demand for investigation of paternal/maternal identity in Brazil, 
public authorities have borne the costs of the ADN testing since 1999. It started in São Paulo and then spread to other Brazilian states. In the last years, with the "human genome" program, promoted massively by the media, ADN testing has become known by a greater number of people. As we know, it is by the means of ADN testing that it is possible to obtain the main form of identifying paternity and maternity of an individual (Guyton, \& Hall, 2006).

In most cases judged at the Family Court using ADN testing, children can usually put on the birth certificate the name of their father and in some cases the name of their mother. For Fonseca (2004), the role of father-provider is an ideal role many men from working class could never achieve. Because of unstable job conditions, many of those men could not provide either financial or affective support to their children, even if they recognized the importance of such bonding.

From the legal point of view, acknowledgment of paternity reflects the consequences in the scope of personality rights, recognized as fundamental by the civil code in its articles 11 and 12. In the practical sphere, the court ruling acknowledging paternity sets a series of responsibilities, such as the duty of intellectual and financial maintenance of the child, as well as general determinations concerning custody, alimony, inheritance in case of succession and others.

Apparently, in the absence of a prior minimum relationship between father and child, legal paternity does not always bring consequences to the practical level-in regard to material support-and much less to the affective level. Nothing assures that the man declared by the court as the father of a certain individual will fulfill his paternal commitment. We have to agree: the statement of a biogenetic fact, the enforcement of a law and the development of a social relationship are distinct processes. In that case, it is difficult to conceive investigation of paternity as a measure to fight poverty, without even this advantage ensured (Thurler, 2004).

Within the acknowledgment policies framework lies the matter of denial of acknowledgement of Brazilian children by male begetters. The paternal acknowledgment has, in addition to a social and affective dimensions, also a formal, legal and judicial aspect, and all those characteristics are equally important for strengthening citizenship of children, fathers and mothers (Thurler, 2006). According to one of the interviewees:

“... that if it really was for myself to register the baby girl, I would have to be really sure that she was indeed my daughter, right” (Interview, Sávio).

We identify in the line above that genetic aspects are considered important factors in order to perform and play this role. Fonseca (2004) reports that, even after having raised their children, there had been cases where some men asked for the genetic paternity testing, what shows that biological bond is still very valued both individually and collectively. When questioned about their relationship with the children, fathers answered:

“... I've followed since, the ... the day she got pregnant". “... after she got pregnant, then she left to Tocantins, got it? Then she stayed a year there, a 
year not, around seven, eight months, then she came here, had the boy, and then she disappeared for five years. After that then she turned up with the boy" (Wilson).

“... I got a little excited I mean, that expectation of... of starting to assimilate, starting to hit me in order to have that feeling of being a father, of course. I am still going to take some time, because kinda that... let's say, a landlubber. Although the child is almost two years old, I am excited, I mean, I am in anticipation of... of giving the best, let's say that way" (Antonio).

It is possible to notice some feelings revealed from paternity testing, what establishes the need for defining a caretaker role and those likely fathers also show good expectations related to the task they would perform if the test proves their paternity. Moreover, it was possible to observe feelings of anxiety, fear and concern. The researches carried out by Dantas et al. (2004) discuss a more effective participation of men in the family routine, especially in child care, the kind of behavior that gradually starts being called "new paternity".

The above-mentioned authors indicate that although the apparent willingness of many fathers to take part in upbringing their children, the symbolic and social support of paternity are still fragile and uncertain, that is, the model of father-provider and mother-caretaker, regent in the bourgeois nuclear family, still seems dominant in the conceptions of Brazilian families.

For Brito (2007, p. 172), the role of the "new" father is mentioned as that one who "recovers a close paternity, empathetic, who discovers the enjoyment of the children, who shares equality with the tasks of the mother". That paternal profile is only possible to occur with a more frequent interaction with children, and in that perspective, Sutter and Bucher-Maluschke (2008) show that, in fact, the novelty are not the feelings, but the way they are expressed, with a physically intimate father, looking for physical and affective contact with his child.

Considering what was discussed, it is possible to realize that many feelings came up generated by the putative "fathers" triggered by the ADN testing. While some felt anxiety and created good expectations concerning their children, others showed angst, anxiety and a certain fear facing such situation. However, it was noticeable that nowadays paternity has a new configuration when it comes to its task and role.

\section{Conclusions}

The study tried to understand the emotional repercussions in fathers triggered by ADN testing for acknowledgment of paternity. Furthermore, there was a characterization of the social profile of the participants and the sentiments of fathers concerning the test were also identified.

It was noticed that there were several forms of reactions from fathers because of the result of the ADN testing: some were pleased and stated that already knew about the paternity confirmation, whereas others showed surprise. Concerning 
the involvement with children's lives, there were fathers who elaborated on their affection and care for their children and others who signaled some insecurity and worry about upbringing and the future of their children. Those differences were allegedly related to the socioeconomic situation at the moment of the test and also to the way the practice of paternity is currently discussed, that is, in a more present way both physically and affectively.

In the study, it was observed that some fathers showed some insecurity concerning paternity and were afraid of being demanded to take part in the caring process of their children. It is possible to see here a more conservative view by some of those fathers when they signal indirectly that the mother is the responsible for the basic child care, what indicates the need for more studies concerning the importance of paternal participation in the emotional, physical and social development of their children.

The study had limitations concerning the number of participants, however it is worth highlighting that the access to them was difficult, and that reflected in the size of the sample. We hope that future studies might be able to investigate the father-child relationship after confirmation of paternity and how those fathers experience it, both psychologically and emotionally.

\section{References}

Andrade, R. P., Costa, N. R. A., \& Rossetti-Ferreira, M. C. (2006). Significações de paternidade adotiva: um estudo de caso. Paidéia, 16, 241-252. https://doi.org/10.1590/S0103-863X2006000200012

Antunes, A. L. M. D. P., Magalhães, A. S., \& Féres-Carneiro, T. (2010). Litígios intermináveis: Uma perpetuação do vínculo conjugal? Aletheia, No. 31, 199-211. http://pepsic.bvsalud.org/scielo.php?script=sci_arttext\&pid=S1413-0394201000010001 $\underline{6}$

Balancho, L. S. F. (2004). Ser pai: Transformações intergeracionais na paternidade. Análise Psicológica, 22, 377-386.

http://www.scielo.mec.pt/scielo.php?script=sci_arttext\&pid=S0870-8231200400020000 $\underline{6}$

Bardin, L. (2004). Análise de conteúdo (3rd ed.). Portugal: Edições 70.

Benczik, E. B. P. (2011). A importância da figura paterna para o desenvolvimento infantil. Revista Psicopedagogia, 28, 67-75.

http://pepsic.bvsalud.org/scielo.php?script=sci_arttext\&pid=S0103-8486201100010000 7

Brasileiro, R. D. F., Jablonski, B., \& Féres-Carneiro, T. (2002). Papéis de gênero, transição para a paternidade e a questão da tradicionalização. Psico, 33, 289-310.

Brito, L. M. T. (2007). Família pós-divórcio: A visão dos filhos. Psicologia: Ciência e profissão, 27, 32-45. https://doi.org/10.1590/S1414-98932007000100004

Brito, L. M. T. (2008). Paternidades contestadas: A definição da paternidade como um impasse contemporâneo. Belo Horizonte: Del Rey.

Brito, L. M. T. D., Cardoso, A. R., \& Oliveira, J. D. G. D. (2010). Debates entre pais e mães divorciadas: Um trabalho com grupos. Psicologia: Ciência e Profissão, 30, 810-823. https://doi.org/10.1590/S1414-98932010000400011

Burdon, B. (1998). Envolvendo os homens na vida familiar: se eles podem fazê-lo, porque não o fazem. In P. Silveira (Ed.), Exercício da paternidade (pp. 81-90). Porto Alegre: 
Artes Médicas.

Carvalho, J. B. L. D., Brito, R. S. D., Araújo, A. C. P. F., \& Souza, N. L. D. (2012). Sentimentos vivenciados pelo pai diante do nascimento do filho. Revista da Rede de Enfermagem do Nordeste, 10, 125-131. http://www.revistarene.ufc.br/vol10n3_pdf/a15v10n3.pdf

Crepaldi, M. A., Andreani, G., Hammes, P. S., Ristoff, C. D., \& Abreu, S. D. (2006). A participação do pai nos cuidados da criança, segundo a concepção de mães. Psicologia em Estudo, 11, 579-587. https://doi.org/10.1590/S1413-73722006000300014

Dantas, C., Jablonski, B., \&Féres-Carneiro, T. (2004). Paternidade: Considerações sobre a relação pais-filhos após a separação conjugal. Paidéia, 14, 347-357. https://doi.org/10.1590/S0103-863X2004000300010

Fonseca, C. (2004). A certeza que pariu a dúvida: Paternidade e DNA. Revista de Estudos Femininos, 12, 13-34. https://doi.org/10.1590/S0104-026X2004000200002

Gabriel, M. R., \& Dias, A. C. G. (2011). Percepções sobre a paternidade: Descrevendo a si mesmo e o próprio pai como pai. Estudos de Psicologia, 16, 253-261.

https://doi.org/10.1590/S1413-294X2011000300007

Goetz, E. R., \& Vieira, M. L. (2010). Pai real, Pai ideal: O papel paterno no desenvolvimento infantil. Curitiba: Juruá.

Gomes, A. J. S., \& Resende, V. R. (2004). O pai presente: O desvelar da paternidade em uma família contemporânea. Psicologia: Teoria e Pesquisa, 20, 119-125.

https://doi.org/10.1590/S0102-37722004000200004

Guyton, A. C., \& Hall, J. E. (2006). Tratado de fisiologia medica (11th ed.). Rio de Janeiro: Elsevier Editora Ltda.

Hurstel, F. (1999). As novas fronteiras da paternidade. Campinas: Papirus.

Instituto Brasileiro de Geografia e Estatística-IBGE (2010). http://www.ibge.gov.br/home/

Lima, F. T. I, Pedroso, J. S., Cruz, E. J. S., \& Aguiar, L. F. (2016). Mothers and Grandmothers in Social Vulnerability: Conceptions about Care and Institutional Shelter. Interpersona: an International Journal on Personal Relationships, 10, 10-21. https://doi.org/10.5964/ijpr.v10isupp1.234

Manfroi, E. C., Macarini, S. M., \& Vieira, M. L. (2011). Comportamento parental e o papel do pai no desenvolvimento infantil. Revista brasileira de crescimento e desenvolvimento humano, 21, 59-69.

http://pepsic.bvsalud.org/scielo.php?script=sci_arttext\&pid=S0104-1282201100010000 $7 \& \operatorname{lng}=\mathrm{pt} \& \mathrm{nrm}=\mathrm{iso}$ https://doi.org/10.7322/jhgd.19996

Muraro, R. M. (1992). A mulher no terceiro milênio. Rio de Janeiro: Rosa dos Tempos.

Oliveira, A. G. D., \& Silva, R. R. (2011). Pai contemporâneo: diálogos entre pesquisadores brasileiros no período de 1998 a 2008. Psicologia argumento, 29, 353-360. http://www2.pucpr.br/reol/pb/index.php/pa?dd1=5293\&dd99=view\&dd98=pb

Polity, E., Setton, M. Z., \& Colombo, S. F. (2004). Ainda existe a cadeira do papai? Conversando sobre o lugar do pai na atualidade. São Paulo: Vetor.

Ramires, V. R. (1997). O Exercício da Paternidade Hoje. Rio de Janeiro: Rosa dos Tempos.

Silva, E. Z. M. (2005). Paternidade ativa na separação conjugal. São Paulo: Editora Juarez de Oliveira.

Silva, M. D. R., \& Piccinini, C. A. (2007). Sentimentos sobre a paternidade e o 
envolvimento paterno: um estudo qualitativo. Estudos de psicologia, 24, 561-573. https://doi.org/10.1590/S0103-166X2007000400015

Sousa, A. M., \& Samis, E. M. (2008). Conflitos, diálogos e acordos em um serviço de psicologia. In L. M. T. Brito (Ed.), Famílias e Separações: Perspectivas da psicologia jurídica (pp. 113-135). Rio de Janeiro: EdUERJ.

Staudt, A. C. P., \& Wagner, A. (2008). Paternidade em tempos de mudança. Psicologia: Teoria e prática, 10, 174-185.

http://pepsic.bvsalud.org/scielo.php?script=sci_arttext\&pid=S1516-3687200800010001 $\underline{3}$

Sutter, C., \& Bucher-Maluschke, J. S. N. F. (2008). Pais que cuidam dos filhos: A vivência masculina na paternidade participativa. Psico, 39, 74-82.

http://revistaseletronicas.pucrs.br/ojs/index.php/revistapsico/article/view/1488/2799

Thurler, A. L. (2004). Paternité et inégalités dans les rapports parentaux: Une analyse de cas brésiliens. CahiersduGenre, 36, 69-88. https://doi.org/10.3917/cdge.036.0069

Thurler, A. L. (2006). Outros horizontes para a paternidade brasileira no século XXI? Sociedade e Estado, 21, 681-707.

https://doi.org/10.1590/S0102-69922006000300007

Turato, E. R. (2003). Tratado de Metodologia Clínico-Qualitativa. Petrópolis: Vozes.

Submit or recommend next manuscript to SCIRP and we will provide best service for you:

Accepting pre-submission inquiries through Email, Facebook, LinkedIn, Twitter, etc. A wide selection of journals (inclusive of 9 subjects, more than 200 journals)

Providing 24-hour high-quality service

User-friendly online submission system

Fair and swift peer-review system

Efficient typesetting and proofreading procedure

Display of the result of downloads and visits, as well as the number of cited articles

Maximum dissemination of your research work

Submit your manuscript at: http://papersubmission.scirp.org/

Or contact psych@scirp.org 